\title{
EFFECTS OF THE 1966-68 ERUPTIONS OF MOUNT REDOUBT ON THE FLOW OF DRIFT GLACIER, ALASKA, U.S.A.
}

\author{
By Matthew Sturm, Carl Benson, and Peter MacKeith*
}

(Geophysical Institute, University of Alaska, Fairbanks, Alaska 99775-0800, U.S.A.)

\begin{abstract}
Mount Redoubt, a volcano located west of Cook Inlet in Alaska, erupted from 1966 to 1968. This eruptive cycle removed about $6 \times 10^{7} \mathrm{~m}^{3}$ of glacier ice from the upper part of Drift Glacier and decoupled it from the lower part during a sequence of jökulhlaups which originated in the Summit Crater and flooded Drift River. The same events blanketed the lower part of the glacier with sand and ash, reducing ice ablation. Normal snowfall, augmented by intense avalanching, regenerated the upper part of the glacier by 1976,8 years after the eruptions. When the regenerated glacier connected with the rest of Drift Glacier, it triggered a kinematic wave of thickening ice accompanied by accelerating surface velocities in the lower part of the glacier. Surface velocities increased by an order of magnitude and were accompanied by thickening of $70 \mathrm{~m}$ or more. At the same time, parts of the upper glacier thinned $70 \mathrm{~m}$. The glacier appears to be returning to its pre-eruption equilibrium condition.
\end{abstract}

RÉSUMÉ. Les effets des éruptions de 1966 à 1968 du Mount Redoubt sur l'écoulement du Drift Glacier, Alaska, U.S.A. Le Mount Redoubt, volcan situé à l'ouest de la Cook Bay en Alaska, fit éruption de 1966 à 1968. Ce cycle éruptif déblaya environ $6 \times 10^{7} \mathrm{~m}^{3}$ de glace sur la partie supérieure du Drift Glacier et le sépara de sa langue au cours d'une séquence de jökulhlaups qui venaient du Summit Crater et causèrent les crues de la Drift River. Les mêmes événements recouvrirent la partie basse du glacier de sables et cendres, ce qui a diminué l'ablation. Les habituelles chutes de neige, accrues de nombreuses avalanches, régénérèrent la partie supérieure du glacier à partir de 1976, 8 ans après l'éruption. Lorsque le glacier régénéré fit

\section{INTRODUCTION}

Mount Redoubt $(3108 \mathrm{~m})$, located $175 \mathrm{~km}$ south-west of Anchorage, is one of more than 40 active volcanos in Alaska. It is an isolated strato-volcano located on the west side of Cook Inlet. Heavy snowfall on the volcano supports over ten distinct glaciers which radiate from the summit region. The youthful volcano is not heavily dissected by valleys; consequently the glaciers form an ice-cap complex described by Vinogradov (1981) as the atrio-valley-glacier type. "Drift Glacier" (unofficial name), which flows from the Summit Crater, is the largest, most deeply incised glacier on the volcano. It has complex geometry including steep ice falls over large cliffs at the confluence of its two main branches. For convenience in this discussion, it has been divided into six zones (Fig. 1). Intense avalanching and trapping of wind-blown snow in the Summit Crater and deep canyons through which Drift Glacier flows result in a vigorous system with high ice flux. Drift River runs past the terminus of Drift Glacier in a narrow gorge with ice on one side and steep rock walls on the other.

Volcanic events have caused profound changes in Drift

*Deceased sa jonction avec le reste du glacier, cela déclancha une onde cinématique par épaississement du glacier et accélération des vitesses de surface dans la partie inférieure. Les vitesses superficielles s'accrurent d'un ordre de grandeur et se sont accompagnées d'un épaississement de $70 \mathrm{~m}$ ou plus. En même temps la partie supérieure s'abaissa de $70 \mathrm{~m}$. Le glacier semble être en train de retrouver ses conditions d'équilibre pré-éruptif.

ZUSAMMENFASSUng. Auswirkungen der Ausbrüche von Mount Redoubt zwischen 1966 und 1968 auf die Bewegung des Drift Glacier, Alaska, U.S.A. Mount Redoubt, ein Vulkan westlich des Cook Inlet in Alaska, brach in den Jahren 1966 bis 1968 aus. Dieser Eruptionszyklus beseitigte etwa $6 \times 10^{7} \mathrm{~m}^{3}$ Gletschereis vom oberen Teil des Drift Glacier und trennte diesen vom unteren Teil während einer Folge von Gletscherläufen, die im Gipfelkrater ihren Ausgang nahmen und den Drift River überfluteten. Dieselben Ereignisse verhüllten den unteren Teil des Gletschers mit Sand und Asche, was zur Abnahme der Ablation führte. Normaler Schneefall, verstärkt durch heftige Lawinenabgänge, regenerierte den oberen Gletscherteil bis 1976, acht Jahre nach den Ausbrüchen. Als der regenerierte Gletscher sich mit dem Rest des Drift Glacier verband, löste er eine kinematische Welle von Eisdickenzunahme aus, verbunden mit einer Erhöhung der Oberflächengerschwindigkeit auf dem unteren Gletscherteil. Die Oberflächengeschwindigkeiten nahmen um eine Grössenordnung $\mathrm{zu}$ und waren von einer Aufhöhung um $70 \mathrm{~m}$ und mehr begleitet. Gleichzeitig sanken Teile des oberen Gletschers um $70 \mathrm{~m}$ ab. Der Gletscher scheint zu seinem Gleichgewichtszustand vor der Eruption zurückzukehren.

Glacier. The historic record, probably incomplete, lists eruptions of Mount Redoubt in 1778, 1819, 1902 (large explosion with voluminous ash ejecta), 1933, and most recently, an eruptive cycle from 1965 to 1968 (Simkin and others, 1981). It is this most recent cycle on which we focus.

The recent volcanic events which have had the most profound effects on Drift Glacier occurred on 24 or 25 January 1966. Voluminous steam and ash eruptions were accompanied by a jokulhlaup which emerged from a point just below the Summit Crater (Post and Mayo, 1971). Other jökulhlaups, including a large one on 4 February 1966, occurred between 1966 and 1968 (personal communication from J. Finch, 1983). Aerial photographs taken by A. Post in 1968 after the jökulhlaups show deeply incised gullies, large moulin-like holes, and cauldron-shaped collapse features in the ice. Sediment deltas originating from ice tunnels could be clearly distinguished (Fig. 2). The water released during these jökulhlaups apparently traveled over the surface and through tunnels in or under Drift Glacier, spilled out over the terminus, and flooded Drift River. The jökulhlaup on 25 January flooded the site of the oil-tanker terminal on Cook Inlet at the mouth of Drift River, forcing the evacuation of a seismic crew (Anchorage Daily News, XIX, No. 149, 1966). The flood carried large icebergs and 


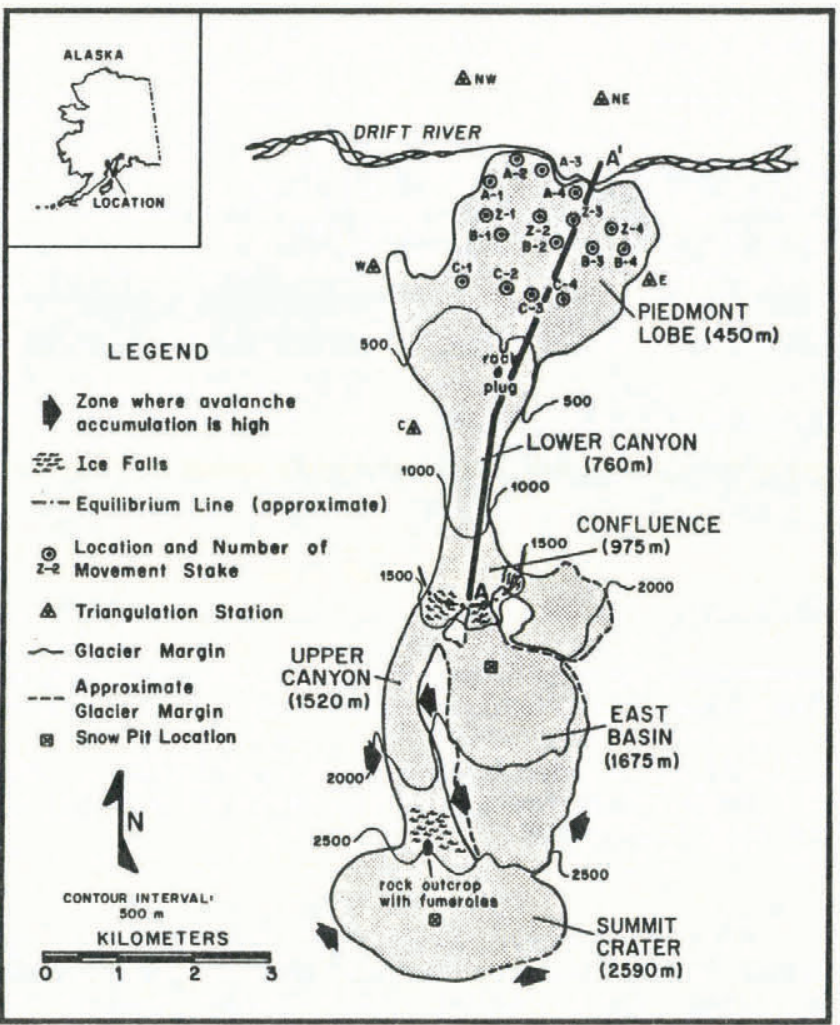

Fig. 1. Drift Glacier on Mount Redoubt, Alaska. The different zones used in the text are shown. Drift River flows past the terminus from west to east.

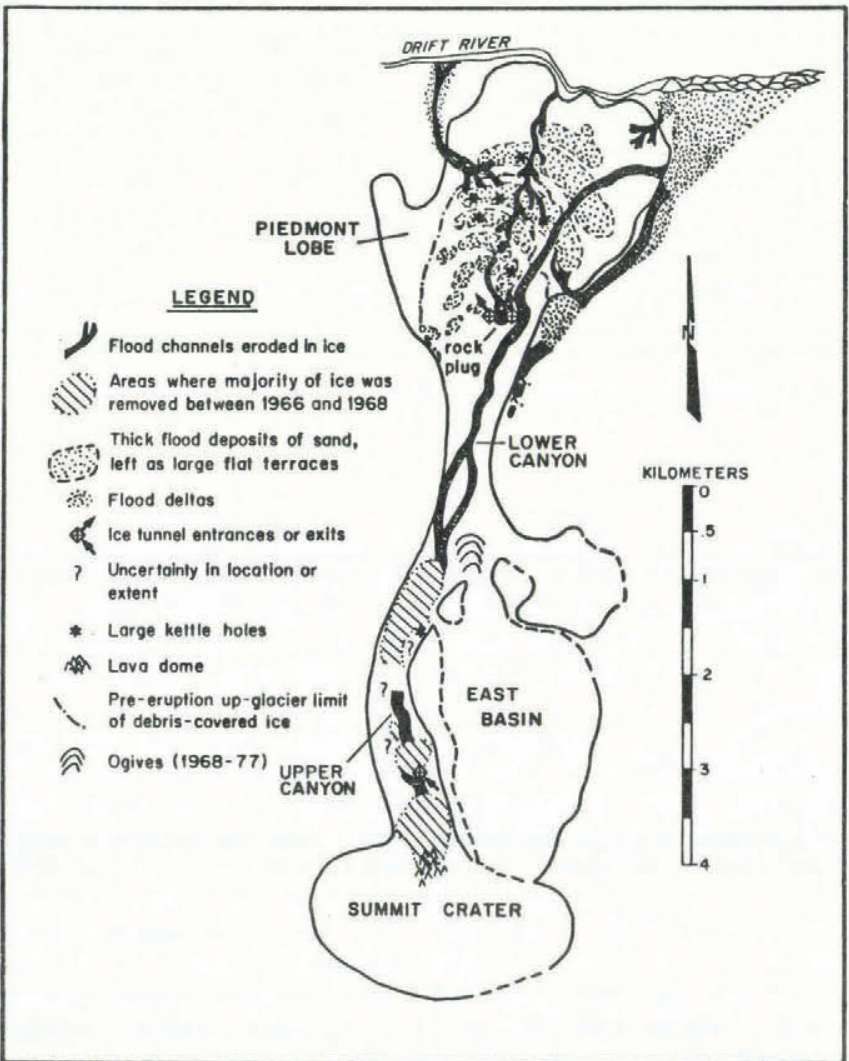

Fig. 2. Erosional and depositional features on Drift Glacier left by the jökulhlaups and eruptions of Mount Redoubt between 1966 and 1968, as compiled from aerial photographs. Ice-tunnel entrances and exits are shown where visible or inferred from deposition of deltaic sediments. Pre-eruption limit of debris cover on the Piedmont Lobe is also shown. deposited a heavy mantle of sand and ash, in places over $5 \mathrm{~m}$ thick, on the Piedmont Lobe of the glacier.

Based on the examination of aerial photographs, an estimated $6 \times 10^{7} \mathrm{~m}^{3}$ of ice was blasted, melted, scoured, and/or washed away by the cumulative events of 1966-68. Most of the ice loss occurred in the Upper Canyon where large sections of the glacier were removed and bedrock was exposed; so little ice remained in place that this branch of the glacier was essentially gone (Fig. 2). This process disconnected the lower part of Drift Glacier from the ice flow out of the Upper Canyon and the Summit Crater, causing a major reduction in the total flux moving through the Lower Canyon and Piedmont Lobe. Large collapse features and deep gullies scoured into the surface of the parts of the glacier which remained suggest that both subglacial and surface melting, and erosion (the jökulhlaups were heavily charged with sand and debris), were involved.

Regeneration began immediately after the eruptive cycle and was essentially complete by 1976. The amount of ice accumulated during this rebuilding stage apparently exceeded that which had been removed by the eruption. When the rebuilding was complete and the regenerated glacier connected with the lower part of the glacier, the increased ice flux produced a bulge of thicker ice which moved down as a kinematic wave through the lower glacier at speeds faster than the normal surface-flow speeds. "Kinematic wave" refers here to the general class of waves which result because changes in flux necessitate changes in thickness and velocity.

Following the development of kinematic wave theory by Lighthill and Whitham (1955), there have been a number of theoretical applications to glaciers beginning with Nye (1960); these were summarized by Paterson (1981). It is not easy to observe kinematic waves in real glaciers. Paterson (1981) cited three examples of phenomena that appeared to be kinematic waves on glaciers. The bulge of thickened ice moving through Drift Glacier in response to profound changes in ice flux is another field example of a kinematic wave.

\section{METHODS}

Three methods have been used to investigate the glacier-volcano events on Mount Redoubt.

\section{Photogrammetry}

Ground-control points for aerial photogrammetry were surveyed in 1977 and 1978. Vertical aerial photographs were taken of Drift Glacier in 1977, 1978, 1979, and 1982. Photogrammetric maps at a scale of $1: 10000$ and contour interval of $5 \mathrm{~m}$ were made from these controlled aerial photographs. From these maps, together with existing USGS maps based on photographs taken in 1954, we prepared longitudinal surface profiles of the glacier accurate to $\pm 2.5 \mathrm{~m}$. These maps and profiles were compared to compute recent changes in thickness and volume of the glacier.

Over 120 oblique and vertical aerial photographs of Drift Glacier, taken between 1938 and 1984, were examined to compile a recent glacier-volcano history. The photographic history was supplemented by interviews with eye-witnesses of the 1966-68 eruptions of Mount Redoubt, including people who witnessed the jökulhlaups on Drift River, and colleagues who studied the eruption (Wilson and others, 1966; Wilson and Forbes, 1969).

\section{Precision surveying}

A stake network (Fig. 1) was established in 1978 on the Piedmont Lobe of Drift Glacier. It has been surveyed one to four times a year since 1978 to measure the surface flow. The stakes, placed in four rows (A, B, C, and D), consist of $3 \mathrm{~m}$ lengths of pipe set in cairns on the thick supraglacial debris. They have required little maintainance because of the relative absence of ablation and surface disturbance. The D row of stakes was an exception to this, surviving less than a year due to heavy crevassing and ablation. A fifth row of stakes $(Z)$ was added between the $A$ and $B$ rows in 1982 for more complete coverage. The stakes have been located by triangulation. Survey errors in horizontal position have not exceeded $\pm 0.2 \mathrm{~m}$. Errors in 
vertical position, mainly due to refraction, have not exceeded $\pm 0.5 \mathrm{~m}$.

\section{Snow pits and cores}

A pit $4 \mathrm{~m}$ deep with a core to $10 \mathrm{~m}$ was excavated in the Summit Crater in 1977. In 1985, a second pit and core to $26 \mathrm{~m}$ was completed in the Summit Crater. In 1983, pit studies were undertaken in the East Basin. Analysis of these pits and cores, together with ablation measurements made in 1978, have enabled us to estimate the mass-balance gradient for Drift Glacier.

\section{RESULTS}

The melting and erosion of most of the glacier in the Upper Canyon during the recent volcanic eruptions, followed by its regeneration in 8 years, is illustrated in Figures 2, 3, and 4 .

The destructive phase (from 1966 to 1968) has three main features:

1. The removal of approximately $6 \times 10^{7} \mathrm{~m}^{3}$ of ice eliminated ice flux from the Upper Canyon to the rest of the glacier (Figs 1 and 2). This reduced the flux through the lower glacier by more than half. Some of the ice which was removed became lodged or buried in the sand or ash which covered the Piedmont Lobe where it slowly melted out during the next few years forming kettle-holes. The majority, however, was either melted or carried to the sea in the jökulhlaups.

2. Approximately $10^{6} \mathrm{~m}^{2}$ of the Piedmont Lobe, as estimated from vertical aerial photographs, was covered by flat terraces composed of sand and ash deposited by the jökulhlaups and eruptions. These deposits were generally greater than $1 \mathrm{~m}$ thick and effectively insulated the ice and eliminated ablation. Similar insulating effects have been discussed by Muller and Coulter (1957), Driedger (1981), and Nakawo and Young (1981). Before the debris was deposited the ablation rate on the Piedmont Lobe was about $5 \mathrm{~m} /$ year. This is based on measurements made in 1978 on the bare ice cliffs at the terminus.

3. The internal and surface water system of Drift Glacier was profoundly altered by the large channels and tunnels cut during the jökulhlaups (Fig. 2). For example, during the jökulhlaups water poured out from the base of the rock plug (Figs 1 and 2) which projects through the lower glacier. This water carved a surface channel which did not exist before the eruptions but persists today and remains one of the dominant drainages on the Piedmont Lobe.

The aerial photographs in Figures 3 and 4 show how quickly the glacier re-formed in the Upper Canyon and re-

A

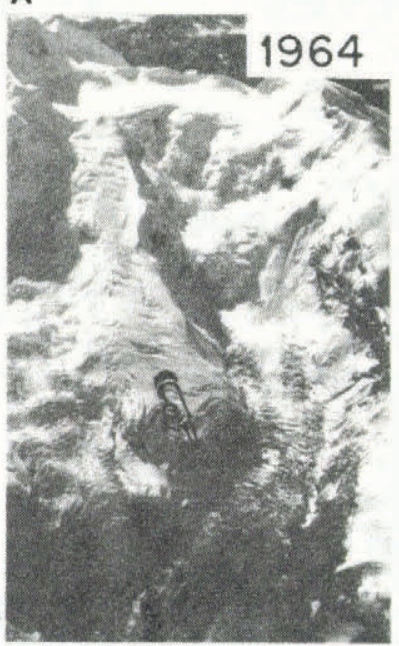

B

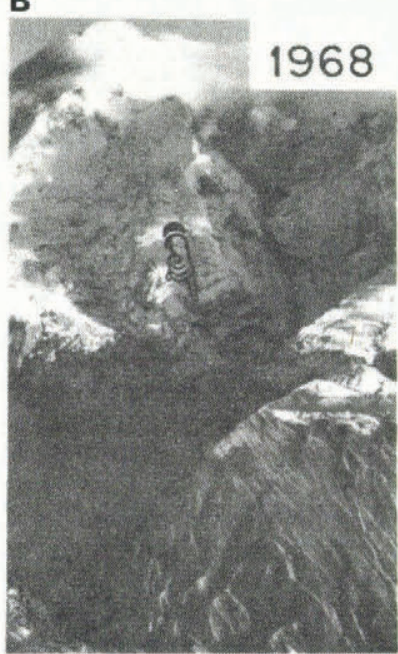

connected with the rest of Drift Glacier. A chronology of events is:

1954-64 (Figs $3 A$ and 4A). The condition of the glacier was "normal", with heavy crevassing throughout the upper parts of the glacier and particularly notable at the confluence of the two main branches. Ogives were absent below the prominent cliffs in the confluence area.

1966-68. Eruptions and jökulhlaups occurred.

1968 (Fig. 3B). The glacier began to re-form in the Upper Canyon.

1970 (Fig. 3C). Avalanching had re-filled part of the Upper Canyon, but bedrock was visible at the confluence of the Upper and Lower Canyons.

1975 (Fig. 3D). The glacier in the Upper Canyon had reformed. It had a steep, lobe-shaped terminus which appeared to be advancing over bedrock but was separated by $200 \mathrm{~m}$ from the main glacier system. Five or six ogives were present below the cliffs on the main glacier in the ice stream from the East Basin.

July 1977 (Fig. 4B). The terminus of the glacier which had re-formed in the Upper Canyon had re-connected and advanced over the glacier in the Lower Canyon. Previously exposed areas of bedrock were covered by crevassed glacier ice. Eight ogives were present.

September 1977 (not shown). The lobe-shaped terminus of the glacier from the Upper Canyon was still recognizable but had advanced $400 \mathrm{~m}$ down the Lower Canyon, over-riding all the ogives and nearly obliterating them.

1978-79 (Fig. 4C and D). A kinematic wave of thickening, accelerating ice had propagated down the glacier. This was accompanied by surface crevassing which progressively disrupted the sand and ash on the glacier surface and made the movement of the wave apparent. Ice originating from the Upper Canyon could still be recognized in the combined ice streams of the Lower Glacier as a zone of clean, white ice.

1982 (Fig. 4E). The kinematic wave continued to propagate through the lower glacier. Surface conditions and crevasse patterns over much of the glacier appeared similar to those in the 1954 photographs.

Mass-balance measurements have been difficult to obtain but are sufficient to estimate the general balance gradient for the glacier. In July 1977, a snow pit with core to $10 \mathrm{~m}$ in the Summit Crater $(2590 \mathrm{~m})$ did not penetrate to

c

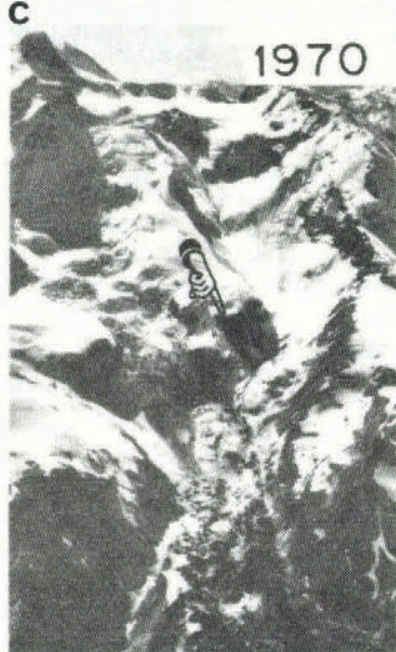

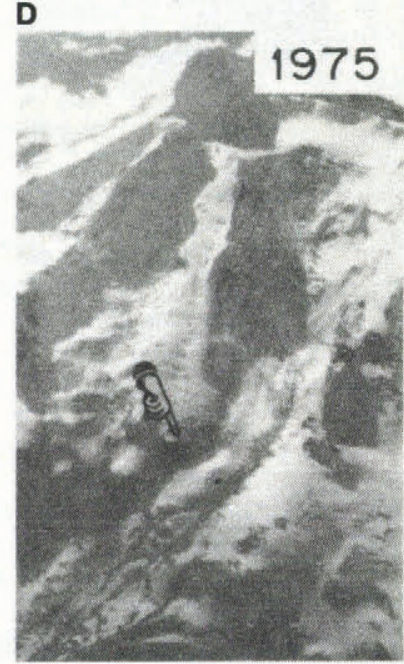

Fig. 3A-D. Oblique aerial photographs taken by A. Post (1964-70) and the authors (1975) showing the destruction and regeneration of the glacier in the Upper Canyon. The pointer is in the same location in each photograph. See text for explanation. 


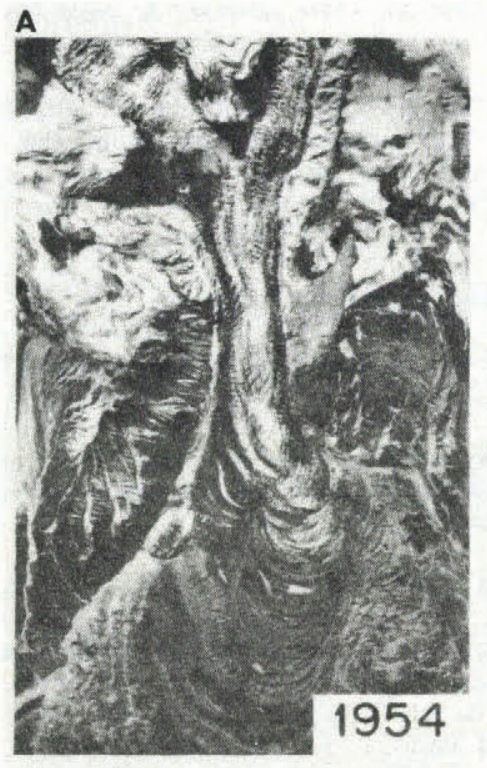

\section{B}
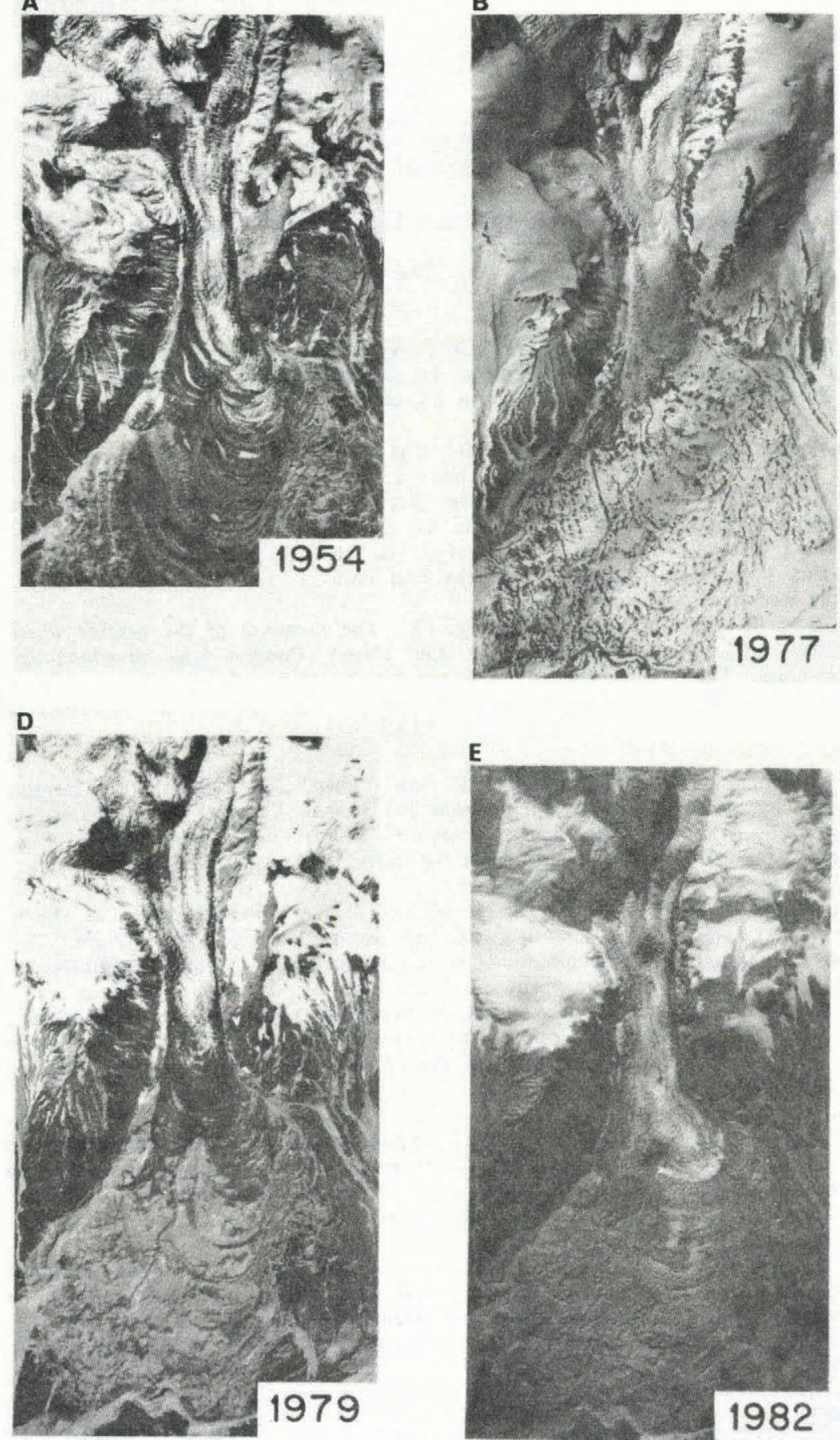

E

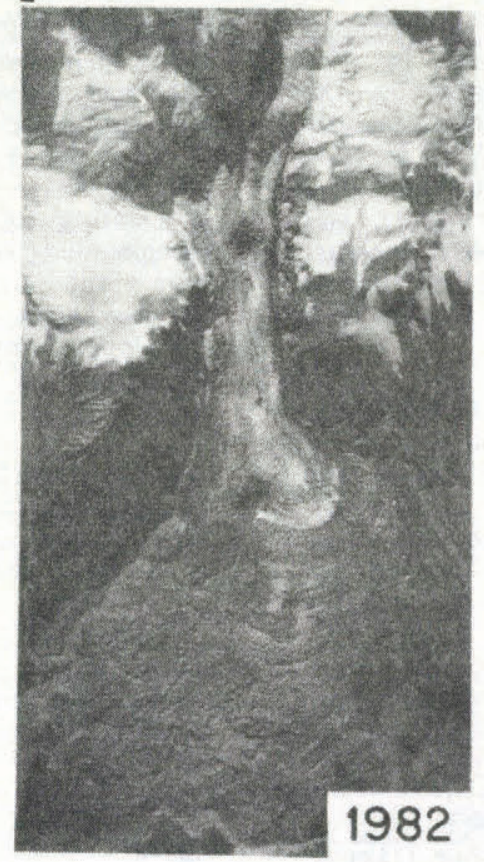

C

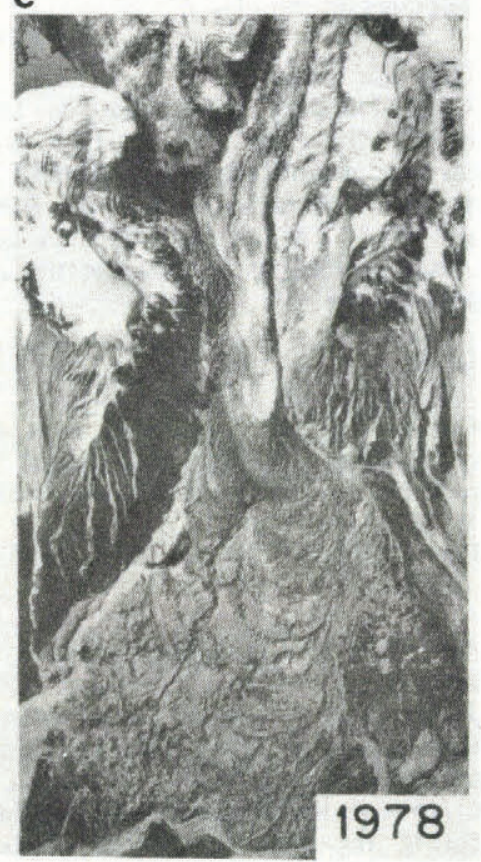

Fig. 4A-F. Vertical aerial photographs of the Lower Canyon and Piedmont Lobe of Drift Glacier showing the pre-eruption condition of the glacier (1954) and the subsequent changes due to the propagation of a kinematic wave through the system (1977-82). The location of the wave front is mapped in Figure 4F. Dashed lines indicate where the front coincided with the terminus of the glacier which re-formed in the Upper Canyon. Dotted lines indicate the front as manifested by the down-glacier limit of new crevassing. Note that the rock plug which divides the flow can be clearly seen in the photographs. In Figure $4 F$, the cross-hatched, white and black parts of the rock plug were ice-free in 1977; the white and black parts of the plug were ice-free in 1979, and the black part of the plug was ice-free in 1982. Note also the similarity in appearance of the glacier in the photographs from 1954 and 1982.

the 1976 summer surface. It revealed a minimum value of $5 \mathrm{~m}$ water equivalent of accumulation for the year 1976-77. A snow pit and core to $26 \mathrm{~m}$ excavated in the Summit Crater in 1985 suggested an average balance of $6.5 \mathrm{~m}$ water equivalent per year for the 2 years of accumulation it penetrated, though there was some difficulty in interpreting the stratigraphy. In 1983, a pit and core in the East Basin at $1400 \mathrm{~m}$ penetrated more than two annual units and indicated an average annual balance of about $0.5 \mathrm{~m}$ water equivalent per year. In 1978, an ablation rate of $5 \mathrm{~m} /$ year was measured on a clean vertical ice face at $300 \mathrm{~m}$. By using an accumulation value of $6.5 \mathrm{~m}$ at the Summit Crater, an ablation rate of $5 \mathrm{~m}$ /year at the terminus, and estimating an equilibrium-line altitude of $1200 \mathrm{~m}$ from late summer photography, we obtain a balance gradient of $0.5 \mathrm{~m}$ water equivalent $/ 100 \mathrm{~m}$ of altitude. This gradient is in general agreement with the gradients of maritime Alaskan glaciers such as Wolverine and Columbia Glaciers (Meier and others, 
1971; Mayo, 1984), and the accumulation in the Summit Crater is in the same range as that measured on Columbia Glacier at the same altitude (Mayo, 1984).

From 1968 to 1976, when there was no ice flux out of the Upper Canyon, glacier ice rapidly accumulated there because accumulation rates in the Upper Canyon and the Summit Crater are high and augmented by avalanches. Avalanching in the upper part of the canyon had covered much of the denuded area by 1970 (Fig. 3C). By 1975 (Fig. 3D) a glacier with a lobe-shaped terminus had re-formed in the Upper Canyon and was within $200 \mathrm{~m}$ of re-connecting with the rest of Drift Glacier. In 1977, the re-connection was complete, and the regenerated lobe had actually over-ridden part of the glacier in the Lower Canyon.

We estimate that approximately $15 \times 10^{7} \mathrm{~m}^{3}$ of ice accumulated in the Summit Crater and Upper Canyon between 1968 and 1976, re-creating the glacier. This ice volume was estimated by applying the balance gradient of $0.5 \mathrm{~m}$ water equivalent per $100 \mathrm{~m}$ of altitude to the areas of the Summit Crater and Upper Canyon, and summing over the 8 years between 1968 and 1976 .
We have also used the balance gradient to estimate the annual balance flux and balance velocity through the equilibrium line for the entire glacier. Applying the balance gradient to the accumulation areas:

$\begin{array}{ll}\text { Summit Crater } & 2.2 \times 10^{6} \mathrm{~m}^{2}, \\ \text { East Basin } & 3.8 \times 10^{6} \mathrm{~m}^{2}, \\ \text { Upper Canyon } & 3.4 \times 10^{6} \mathrm{~m}^{2},\end{array}$

the annual ice flux through the equilibrium line is $3.0 \times$ $10^{7} \mathrm{~m}^{3}$. If we assume a deep, parabolic cross-section and plug flow, the balance velocity through the Lower Canyon is $450 \mathrm{~m}$ /year.

Curiously (and fortuitously), during the time when ice flux from the Upper Canyon was cut off from the Drift Glacier system, the remaining flow from the East Basin began to form ogives below an ice fall at the head of the Lower Canyon. These ogives, which formed only during this period of time, can be seen in Figure 4B. We identify eight ogives, which represent the 8 years of missing flux from the Upper Canyon. Similarly, six ogives can be seen in the

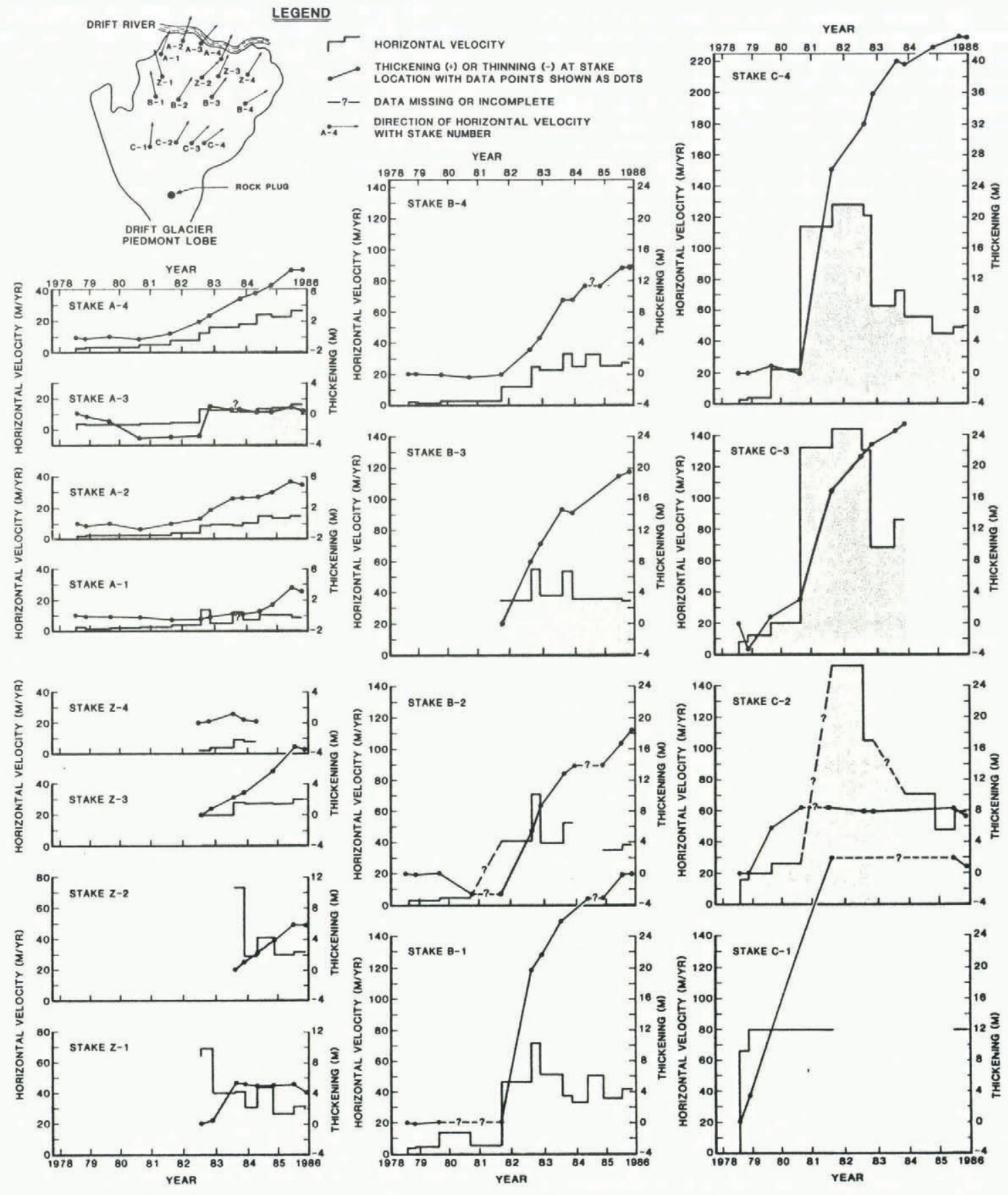

Fig. 5. Plots of surface velocity and ice thickening for stakes on the Piedmont Lobe. 
lower left corner of the 1975 photograph (Fig. 3D). The ogives, over-run and obliterated by the lobe of ice from the Upper Canyon in 1977-78, have not been noted since then. They are a visible manifestation of the different flow regime which existed in the glacier of the Lower Canyon during this period when there was no ice flux from the Upper Canyon. For the period when there was only flow out of the East Basin the ogives give an approximate surface velocity of $315 \mathrm{~m} /$ year, assuming they form annually by seasonal variation in flow. This value, for the East Basin component, is less than the balance velocity for the entire glacier by more than $100 \mathrm{~m} /$ year.

The speed at which the lobe-shaped terminus of the regenerated glacier advanced has been computed from photographs (Fig. 4A-E) to be:

$\begin{array}{lr}1975-77 & 450 \mathrm{~m} / \text { year } \\ \text { July-September } 1977 & 1200 \mathrm{~m} / \text { year } \\ 1977-78 & 1300 \mathrm{~m} / \text { year } \\ 1978-79 & 520 \mathrm{~m} / \text { year } \\ 1979-82 & 210 \mathrm{~m} / \text { year. }\end{array}$

These speeds actually represent three closely related phenomena. The speed before 1977 is the speed of the terminus advancing over bedrock. In 1977 and 1978, after re-connection with the main glacier, the speed is the movement of the frontal lobe of the over-riding ice. From 1978 onward, however, this front was obscure, and the speeds give the rate of advance of the down-glacier edge of new crevassing. The latter speeds have been supplemented by survey data which recorded the onset of ice acceleration and thickening as it passed through the stake network on the Piedmont Lobe. The abrupt decrease in speed of the front between 1978 and 1979 corresponds with the time that it moved out of the confined Lower Canyon. Following the re-connection of its two branches, the speeds are essentially those at which the kinematic wave propagated through Drift Glacier. The propagation speeds were generally 3-5 times the average surface velocity of the glacier in the same area.

The survey data for the stake network give a clear picture of how the kinematic wave of thickening ice, accompanied by increasing surface velocity, has propagated through the Piedmont Lobe (Fig. 5). However, the propagation has been complicated by the presence of the rock plug as there are differences in the speed and direction of propagation between the east and the west components. The rock plug has also served as an indicator of the ice thickening (Fig. 4F). Before 1979, helicopters could land on the top of it but in 1982 it was covered by ice seracs, a thickening of over $50 \mathrm{~m}$.

The surface velocity throughout the Piedmont Lobe was less than $10 \mathrm{~m} /$ year when first measured in 1978. By 1979 the flow had begun to accelerate at the $C$ row of stakes. This acceleration progressed down-glacier through the $\mathrm{B}$ and the A rows. It took about a year to move from one row of stakes to the next $(\sim 1 \mathrm{~km})$. Acceleration of the $C$ row began in 1980-81, although stake C-1, which is located in the western component of flow, began to accelerate as early as 1979. Acceleration of the B row began in 1981 and acceleration on the $A$ row began in 1982. Data for the $Z$ row, which was emplaced in 1982, are included for completeness and suggest that acceleration began there in 1982. In general, flow speeds increased an order of magnitude or more.

The data suggest that surface velocities have peaked and begun to decrease in the $\mathrm{C}$ and $\mathrm{B}$ rows of stakes. This implies that the kinematic wave has taken about 5 years to move past the $\mathrm{C}$ row of stakes. We must be cautious in this interpretation, however, because the summer velocity of Drift Glacier is $20-25 \%$ greater than the winter velocity. Depending on the timing of the spring and autumn surveys, more or less of the high-velocity summer component can be included in a measurement. Inclusion of a greater percentage of summer component can account for the appearance of a velocity peak in the B row in 1982 but is insufficient to account for the peak in the $C$ row, which shows a real deceleration.

The thickening which accompanied the acceleration is shown in Figures 5 and 6. Maximum thickening, measured by surveying at stake C-4, was over $40 \mathrm{~m}$, although greater thickening $(70 \mathrm{~m})$ was measured photogrammetrically at other points on the Piedmont Lobe.

Intense crevassing took place after the onset of thickening and was preceded down-glacier by a noticeable warping of the flat sand and ash terraces (Fig. 2) into transverse synclinal folds with wavelengths of tens of meters. The crevassing progressively disrupted the terraces. Initially, small longitudinal cracks formed in the surface debris but within a year or two the glacier surface became a chaotic jumble of crevasses and blue fins of ice. The debris fell into the crevasse openings and ablation began where debris was removed. The longitudinal and radial crevasses can be seen clearly in Figure 4E.

Longitudinal profiles of the glacier for the years 1954 1977, 1978, 1979, and 1982 are shown in Figure 6. They have been extended up-glaicer to the ice fall at the confluence of the East Basin and the Upper Canyon, which is as far as photogrammetric control would allow. They confirm that steady ice thickening occurred in the Piedmont Lobe since 1977, but also show that thinning has taken place in the upper reaches at the confluence of the two branches of the glacier.

The glacier profile in the Lower Canyon was thickest in 1977 and probably indicates that the kinematic wave was passing through the canyon at that time. Thinning followed rapidly in 1978. By 1982 , over $70 \mathrm{~m}$ of thinning had taken place at the narrowest part of the canyon. In this same vicinity, stranded fringes of glacier ice over $50 \mathrm{~m}$ above the glacier surface were noted in 1982. This stranded ice is similar to stranded ice observed on Variegated and Muldrow Glaciers after their surges (Harrison, 1964; Post and LaChapelle, 1971; Kamb and others, 1985).

The transition between zones of ice thinning and thickening occurs at the exit of the Lower Canyon, where the glacier begins to spread out on the Piedmont Lobe. This point of zero change in surface elevation has remained nearly stationary throughout the period for which we have data.

Using a simple model of prismatic volume elements based on the longitudinal profiles, the total volume lost due to thinning of the upper part of the glacier and the total volume gained due to thickening of the lower part of the glacier from 1978 to 1982 were calculated. Effects of residual annual snow-pack on the volumes have been ignored. We find that $8.6 \times 10^{7} \mathrm{~m}^{3}$ of ice were added to the lower part, while $4.0 \times 10^{7} \mathrm{~m}^{3}$ were lost from the fraction of the upper part covered by our maps.

\section{DISCUSSION}

Volcanic eruptions during 1966 through 1968 reduced the flux of the lower part of Drift Glacier by more than $50 \%$. Ice flux from the Upper Canyon and Summit Crater was eliminated for 8 years. The glacier in the Upper Canyon re-formed rapidly and re-connected with the main system in 1976. The re-connection more than doubled the flux and produced a kinematic wave which has propagated through the glacier and been observed by our surveying and photogrammetry.

The passage of the kinematic wave appears to be returning the glacier to its pre-eruption equilibrium condition. This can be seen by examining the general condition of the glacier before the eruption (Fig. 4A) and in the most recent photographs (Fig. 4E). The present condition of the glacier, including surface crevassing, thickness where ascertainable, and overall longitudinal profile, is similar to the pre-eruption condition. Note, for example, the close similarity between the 1954 and 1982 profiles (Fig. 6).

The regenerated glacier apparently had more mass at the time it re-connected than it did prior to the eruption. This is suggested by two lines of evidence. First, our calculation that about twice as much ice accumulated in the Upper Canyon and Summit Crater, during the 8 years of its rebuilding, than was lost during the eruption. Secondly, Figure 5 shows an order-of-magnitude increase in velocity as the ice thickened followed by a decrease in velocity to levels that were still significantly higher than they were before the ice thickened. This suggests an initial surge of higher flux as the excess mass in the upper glacier was 


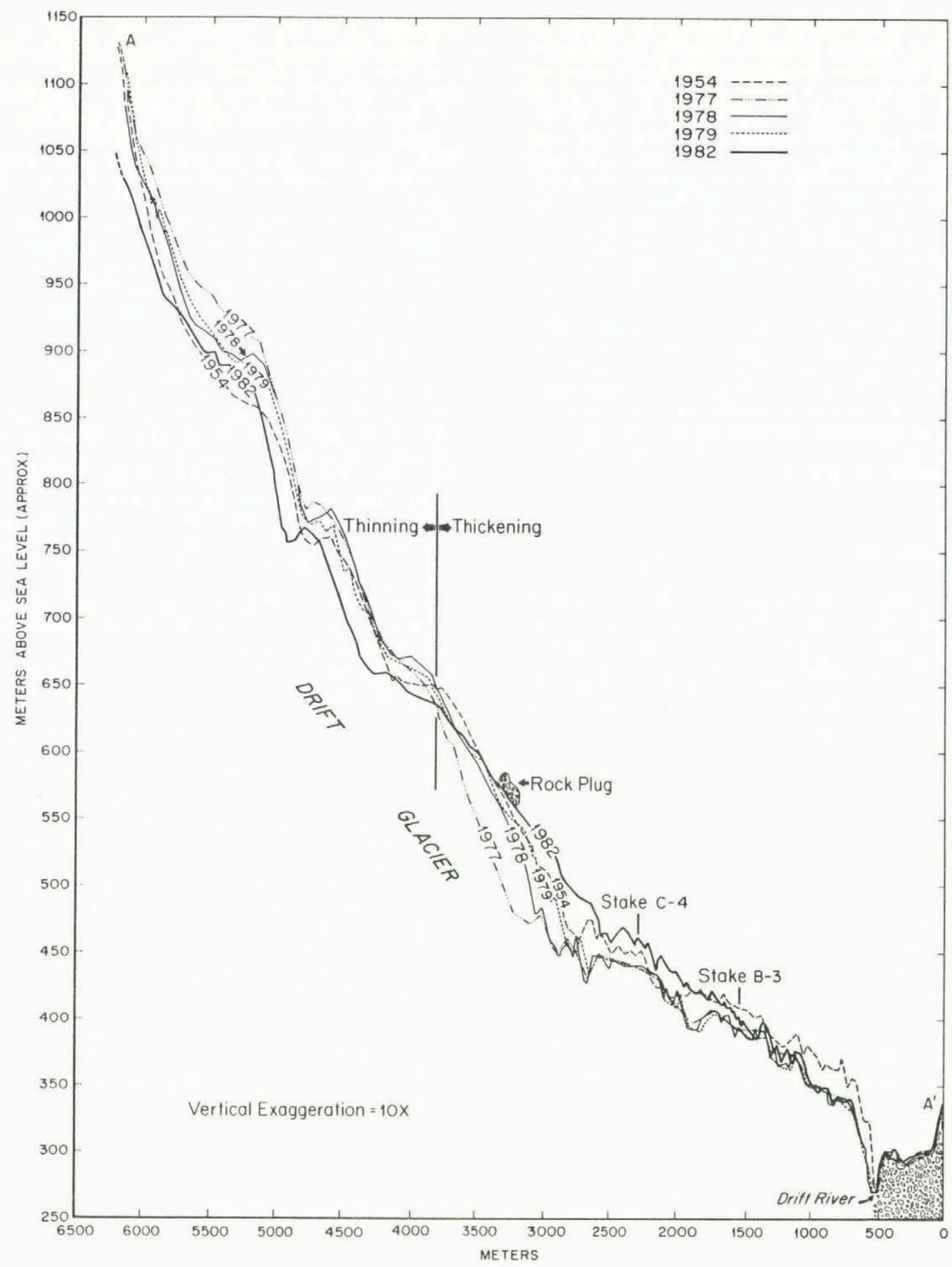

Fig. 6. Longitudinal surface profiles of the Drift Glacier Lower Canyon and Piedmont Lobe. Location of
the profiles is shown in Figure 1.

discharged immediately after the re-connection, followed by a slightly reduced flux as the system came to equilibrium. At the same time that ice was removed from the Upper Canyon, debris was deposited on the Piedmont Lobe. This reduced ablation and allowed the ice to thicken as the flow continued out of the East Basin. The reduced ablation resulted in a surplus of $7 \times 10^{7} \mathrm{~m}^{3}$ of ice compared to the amount which would have been lost had the debris cover not been present. Thickening during the same time was $9 \times 10^{7} \mathrm{~m}^{3}$. However, the thickening of the Piedmont Lobe must be a combination of both reduced ablation and thickening resulting from the passage of the kinematic wave. The kinematic wave can be identified by its effects on the ice such as crevassing, the associated loss of debris cover, and the onset of melting.
Changes in velocity on the Piedmont Lobe observed between 1979 and 1986 cannot be explained by changes in glacier thickness and surface slope alone. Some change in basal sliding seems likely. For example, between 1981 and 1982, the velocity at stake C-3 increased from 20 to $115 \mathrm{~m} /$ year. During the same period, the ice thickness increased less than $25 \mathrm{~m}$, while the general surface slope increased at most a few degrees. Assuming a conservative ice thickness of $200 \mathrm{~m}$, theory (Nye, 1952; Paterson, 1981) indicates at most an increase in velocity of $20 \mathrm{~m} /$ year. Changes in internal glacier plumbing as a result of the jökulhlaups, or diminished water supply because of reduced ablation on the Piedmont Lobe, may have contributed to changes in basal sliding, but it appears likely that the kinematic wave affected basal sliding as it passed. 
The events on Drift Glacier were caused by a dramatic external event - a volcanic eruption - but it is interesting to note some of the strong similarities between these events and those observed during a glacier surge. In the period from 1978 to the present, we observed an order-ofmagnitude increase in surface velocity along with thickening and crevassing of the glacier surface. There was a net displacement of mass from an upper to a lower zone of the glacier. Based on these characteristics, it would be possible to classify Drift Glacier as type III in Meier and Post's (1969) system of surge glaciers. Although Drift Glacier is not considered to be a surge glacier, we are left to wonder what mechanisms it might have in common with surging glaciers.

By 1986 the kinematic wave appeared to be attenuating and had passed through most of the survey net. However, if the kinematic wave propagates to the terminus and causes it to advance by even $25 \mathrm{~m}$, it would potentially dam Drift River (Fig. 1) and impound a glacier-dammed lake as it has done in the past (personal communication from A. Till, 1984). This would pose a new threat to the oil-tanker terminal at the mouth of Drift River.

\section{ACKNOWLEDGEMENTS}

This research was financially supported by the Division of Geological and Geophysical Surveys (DGGS) of the Alaska Department of Natural Resources. Logistical support for this work has been generouly supplied by the Cook Inlet Pipe Line Co., the U.S. Bureau of Land Management OCSEAP office, the Alaska DGGS, the U.S. National Park Service, the U.S. Geological Survey, and the State of Alaska.

\section{REFERENCES}

Driedger, C.L. 1981. Effect of ash thickness on snow ablation. (In Lipman, P.W., and Mullineaux, D.R., eds. The 1980 eruptions of Mount St. Helens, Washington. Washington, DC, U.S. Geological Survey, p. 757-60. (Professional Paper 1250.))

Harrison, A.E. 1964. Ice surges on the Muldrow Glacier, Alaska. Journal of Glaciology, Vol. 5, No. 39, p. 365-68.

Kamb, W.B., and others. 1985. Glacier surge mechanism: 1982-1983 surge of Variegated Glacier, Alaska, by W.B. Kamb [and 7 others]. Science, Vol. 227, No. 4686, p. 469-79.
Lighthill, M.J., and Whitham, B.G. 1955. On kinematic waves. Proceedings of the Royal Society of London, Ser. A, Vol. 229, p. 281-345.

Mayo, L.R. 1984. Glacier mass balance and runoff research in the U.S.A. Geografiska Annaler, Vol. 66A, No. 3, p. 215-27.

Meier, M., and Post, A. 1969. What are glacier surges? Canadian Journal of Earth Sciences, Vol. 6, No. 4, Pt. 2, p. $807-17$.

Meier, M., and others. 1971. Combined ice and water balances of Gulkana and Wolverine glaciers, Alaska and South Cascade Glacier, Washington, 1965 and 1966 hydrologic years, by M. Meier, W.V. Tangborn, L.R. Mayo, and A. Post. U.S. Geological Survey. Professional Paper 715-A.

Muller, E.H., and Coulter, H.W. 1957. The Knife Creek glaciers of Katmai National Monument, Alaska. Journal of Glaciology, Vol. 3, No. 22, p. 116-22.

Nakawo, M., and Young, G.J. 1981. Field experiments to determine the effect of a debris layer on ablation of glacier ice. Annals of Glaciology, Vol. 2, p. 85-91.

Nye, J.F. 1952. The mechanics of glacier flow. Journal of Glaciology, Vol. 2, No. 11, p. 82-93.

Nye, J.F. 1960. The response of glaciers and ice-sheets to seasonal and climatic changes. Proceedings of the Royal Society of London, Ser. A, Vol. 256, No. 1287, p. 559-84.

Paterson, W.S.B. 1981. The physics of glaciers. Second edition. Oxford, etc., Pergamon Press. (Pergamon International Library.)

Post, A., and LaChapelle, E.R. 1971. Glacier ice. Seattle, The Mountaineers; Seattle, etc., University of Washington Press.

Post, A., and Mayo, L. 1971. Glacier dammed lakes and outburst floods in Alaska. U.S. Geological Survey. Hydrologic Atlas HA-455.

Simkin, T., and others. 1981. Volcanos of the world, by $T$. Simkin, L. Siebert, L. McClelland, D. Bridge, C. Newhall, and J.H. Latter. Stroudsburg, PA, Hutchinson Ross Publishing Co.

Vinogradov, V.N. 1981. Glacier erosion and sedimentation in the volcanic regions of Kamchatka. Annals of Glaciology, Vol. 2, p. 164-69.

Wilson, C.R., and Forbes, R.B. 1969. Infrasonic waves from Alaskan volcanic eruptions. Journal of Geophysical Research, Vol. 74, No. 18, p. 4511-22.

Wilson, C.R., and others. 1966. Evidence of two sound channels in the polar atmosphere from infrasonic observations of the eruption of an Alaskan volcano, by C.R. Wilson, S. Nichparenko, and R.B. Forbes. Nature, Vol. 211 , No. 5045 , p. 163-65. 